\title{
Removal of 4-hydroxyphenylacetic acid from aqueous medium by electrochemical oxidation with a BDD anode: Mineralization, kinetics and oxidation products
}

\author{
Nelly Flores, Ignasi Sirés *, Rosa María Rodríguez, Francesc Centellas, Pere Lluís Cabot, \\ José Antonio Garrido, Enric Brillas*
}

Laboratori d'Electroquímica dels Materials i del Medi Ambient, Departament de Química Física, Facultat de Química, Universitat de Barcelona, Martí i Franquès 1-11, 08028 Barcelona, Spain

\section{A R T I C L E I N F O}

\section{Article history:}

Received 27 June 2016

Received in revised form 29 July 2016

Accepted 31 July 2016

Available online $\mathrm{xxxx}$

\section{Keywords:}

Anodic oxidation

By-products

Hydroxyl radical

4-Hydroxyphenylacetic acid

Water treatment

\begin{abstract}
A B S T R A C T
The degradation of $100 \mathrm{~mL}$ of solutions containing 4-hydroxyphenylacetic acid in $0.050 \mathrm{M} \mathrm{Na}_{2} \mathrm{SO}_{4}$ at pH 3.0 has been performed by anodic oxidation with electrogenerated $\mathrm{H}_{2} \mathrm{O}_{2}\left(\mathrm{AO}-\mathrm{H}_{2} \mathrm{O}_{2}\right)$ using a stirred tank reactor equipped with a boron-doped diamond (BDD) anode and an air-diffusion cathode. An almost total mineralization with 95.5\% total organic carbon (TOC) removal was achieved for a $1.03 \mathrm{mM}$ substrate solution at $100 \mathrm{~mA} \mathrm{~cm}^{-2}$. The effect of current density between 16.7 and $100 \mathrm{~mA} \mathrm{~cm}^{-2}$ and 4-hydroxyphenylacetic acid content between 0.21 and $2.06 \mathrm{mM}$ was examined. Greater current efficiency with lower specific energy consumption and smaller mineralization was found at low current density and high substrate concentration. The TOC abatement as well as the 4hydroxyphenylacetic acid concentration decay obeyed a pseudo-first-order kinetics. The oxidation role of hydroxyl radical formed from water discharge at the BDD anode is explained on the basis of its electrogeneration rate and competitive wasting reactions. 4-Hydroxybenzenemethanol and its derivative 4-hydroxybenzenealdehyde were identified as primary aromatic by-products by gas chromatography-mass spectrometry. Ion-exclusion HPLC allowed the detection of low amounts of the persistent oxalic acid during the $\mathrm{AO}-\mathrm{H}_{2} \mathrm{O}_{2}$ process. The remaining TOC in final electrolyzed solutions is related to the presence of a large proportion of unidentified by-products that are even more recalcitrant than common short-chain aliphatic carboxylic acids.
\end{abstract}

(c) 2016 Elsevier B.V. All rights reserved.

\section{Introduction}

The olive oil production in Mediterranean countries such as Spain, Portugal, Greece and Italy accounts for near $77 \%$ of world output. The extraction of olive oil causes the annual release of $>30$ million cubic meters of industrial effluents worldwide. Olive oil mill wastewater (OOMW) has an acidic $\mathrm{pH}$ near 5 and is highly hazardous for the aquatic environment because it presents a chemical oxygen demand up to $110 \mathrm{~g} \mathrm{~L}^{-1}$, a biochemical oxygen demand up to $170 \mathrm{~g} \mathrm{~L}^{-1}$ and total solids concentration up to $150 \mathrm{~g} \mathrm{~L}^{-1}$ [1,2]. The organic components of OOMW include phenols, lipids, sugars and tannins, related to up to $37 \%$ of its total mass $[3,4]$. Several authors have reported the treatment of these effluents by catalytic wet air oxidation [5] and electrochemical degradation with a Pt anode [6,7], which lead to a significant reduction of phenolic derivatives. In order to establish an optimum integral treatment of such wastewater, the degradation of its main single components has to be addressed. 4Hydroxyphenylacetic acid is one of the most abundant phenolic components detected in OOMW, also found in beer. At industrial level, it is used as intermediate in the production of $\beta$-blockers like atenolol and other chemicals. It is a primary product upon oxidation of tyrosol (4-

\footnotetext{
* Corresponding authors.

E-mail addresses: i.sires@ub.edu (I. Sirés), brillas@ub.edu (E. Brillas).
}

hydroxyphenylethanol), another phenolic compound in OOMW $[8,9]$. However, little information is available about the degradation of 4hydroxyphenylacetic acid for wastewater treatment. Only its removal by several advanced oxidation processes (AOPs) such as zero-valent iron [10] and $\mathrm{UV} / \mathrm{H}_{2} \mathrm{O}_{2}$ and Fenton's reagent [11] has been described, but the use of powerful electrochemical AOPs (EAOPs) for treating wastewater contaminated with 4-hydroxyphenylacetic acid has not been reported yet.

EAOPs are environment-friendly technologies that operate at mild conditions without addition of noxious chemicals since the main oxidant is produced by the electron [12-15]. The great oxidation power of these methods to destroy the organic matter in wastewater is related to the continuous in situ production of reactive oxygen species (ROS), pre-eminently the powerful hydroxyl radical $(\cdot \mathrm{OH})$. This species, the second strongest oxidant known after fluorine, possesses such a high standard reduction potential $\left(E^{\circ}\left(\cdot \mathrm{OH} / \mathrm{H}_{2} \mathrm{O}\right)=2.80 \mathrm{~V} / \mathrm{SHE}\right)$ that can non-selectively react with most organics via dehydrogenation and/or hydroxylation up to their mineralization (conversion into $\mathrm{CO}_{2}$, water and inorganic ions) [13]. Anodic oxidation (AO), also called electrochemical oxidation, is the most popular EAOP. In this procedure, a solution with organic pollutants is placed in the electrolytic cell to be oxidized either by direct charge transfer at the anode $\mathrm{M}$ or, if a high current is applied, by adsorbed hydroxyl radical $\mathrm{M}(\bullet \mathrm{OH})$ formed as 
intermediate of $\mathrm{O}_{2}$ evolution from water oxidation [13,16,17]. The oxidation ability of AO depends on the selected anode. It has been found that the most potent one is the boron-doped diamond (BDD) thinfilm electrode in which the physisorbed $\operatorname{BDD}(\bullet \mathrm{OH})$ is produced from the following reaction $[16,18,19]$ :

$\mathrm{BDD}+\mathrm{H}_{2} \mathrm{O} \rightarrow \operatorname{BDD}(\cdot \mathrm{OH})+\mathrm{H}^{+}+\mathrm{e}^{-}$

The use of the BDD anode presents important technological advantages such as remarkable corrosion stability in harsh media, inert surface with low adsorption of $\mathrm{BDD}(\cdot \mathrm{OH})$ and organics and a greater $\mathrm{O}_{2}-$ evolution overvoltage than other anodes. These characteristics significantly upgrade the removal of organic pollutants by hydroxyl radicals $[13,16]$, allowing the mineralization of aromatics [14,18,20-29] and by-products like aliphatic carboxylic acids [30], with much higher oxidation ability than traditional anodes like $\mathrm{Pt}$ [31-33] and $\mathrm{PbO}_{2}$ [34].

An alternative to raw $\mathrm{AO}$ relies on its combination with electrogenerated $\mathrm{H}_{2} \mathrm{O}_{2}$, so-called $\mathrm{AO}-\mathrm{H}_{2} \mathrm{O}_{2}$. In this procedure, $\mathrm{H}_{2} \mathrm{O}_{2}$ is continuously produced by the two-electron cathodic reduction of injected pure $\mathrm{O}_{2}$ or air via reaction (2) $[12,13]$ :

$\mathrm{O}_{2}+2 \mathrm{H}^{+}+2 \mathrm{e}^{-} \rightarrow \mathrm{H}_{2} \mathrm{O}_{2}$

Effective cathodes for reaction (2) include carbonaceous materials like BDD [35], activated carbon fiber [36], carbon nanotubes [37], carbon sponge [38], carbon felt [39-41] and carbon-polytetrafluoroethylene (PTFE) gas diffusion composites [14,15,42,43].

$\mathrm{AO}-\mathrm{H}_{2} \mathrm{O}_{2}$ has been developed in our laboratory using a gas-diffusion cathode $[12,43]$, which minimizes the possible cathodic reduction of organics because of the very efficient supply of $\mathrm{H}_{2} \mathrm{O}_{2}$ to the medium from reaction (2). We have found that the concentration of this species attains a quasi-steady state once its electrogeneration and removal rates equate. $\mathrm{H}_{2} \mathrm{O}_{2}$ is mainly destroyed upon oxidation to $\mathrm{O}_{2}$ at the BDD anode, thus forming hydroperoxyl radical from reaction (3). Therefore, in $\mathrm{AO}-\mathrm{H}_{2} \mathrm{O}_{2}$, organic pollutants can be removed by $\mathrm{BDD}(\bullet \mathrm{OH})$ and, to much smaller extent, by other weaker oxidants like $\mathrm{H}_{2} \mathrm{O}_{2}$ and $\mathrm{BDD}\left(\mathrm{HO}_{2} \bullet\right.$ ).

$\mathrm{BDD}+\mathrm{H}_{2} \mathrm{O}_{2} \rightarrow \mathrm{BDD}\left(\mathrm{HO}_{2} \bullet\right)+\mathrm{H}^{+}+\mathrm{e}^{-}$

This paper reports a study on the degradation of acidic solutions of 4-hydroxyphenylacetic acid by $\mathrm{AO}-\mathrm{H}_{2} \mathrm{O}_{2}$ using a BDD/air-diffusion tank reactor. The influence of current density $(j)$ and substrate content on degradation rate, mineralization current efficiency (MCE) and energy consumption was examined. The decay kinetics of 4-hydroxyphenylacetic and the evolution of generated carboxylic acids were monitored by high-performance liquid chromatography (HPLC). The degradation process was ascertained by identifying the products using gas chromatography-mass spectrometry (GC-MS).

\section{Experimental}

\subsection{Chemicals}

4-Hydroxyphenylacetic acid (98\% purity) was purchased from Sigma-Aldrich and used as received. Analytical grade oxalic acid and anhydrous $\mathrm{Na}_{2} \mathrm{SO}_{4}$ were supplied by Merck and Fluka, respectively. Analytical grade $\mathrm{H}_{2} \mathrm{SO}_{4}$ purchased from Acros Organics was used to adjust the initial $\mathrm{pH}$ to 3.0. All the aqueous solutions were prepared with ultrapure water from a Millipore Milli-Q system (resistivity $>18 \mathrm{M} \Omega \mathrm{cm}$ at $25^{\circ} \mathrm{C}$ ). Other chemicals used for analysis were of HPLC or analytical grade provided by Panreac and Merck.

\subsection{Electrolytic System}

All the trials were carried out in an open, undivided, cylindrical glass cell containing $100 \mathrm{~mL}$ solutions. The cell was surrounded with a double jacket where water was recirculated at $35{ }^{\circ} \mathrm{C}$ regulated by a Thermo Electron Corporation HAAKE DC 10 thermostat. This temperature was the maximum value that could be used to avoid significant solvent evaporation. All the assays were performed under vigorous stirring with a magnetic bar at $700 \mathrm{rpm}$ for homogenization and for ensuring maximum mass transport of reactants toward/from the electrodes. A $3 \mathrm{~cm}^{2}$ BDD (deposited onto $p$-Si) electrode supplied by NeoCoat (LaChaux-de-Fonds, Switzerland) was used as the anode and a $3 \mathrm{~cm}^{2}$ carbon-PTFE air-diffusion electrode supplied by E-TEK (Somerset, NJ, USA) was used as the cathode. The interelectrode gap was about $1 \mathrm{~cm}$. The cathode was mounted as reported elsewhere [42] and was fed with air pumped at $300 \mathrm{~mL} \mathrm{~min}^{-1}$ for continuous $\mathrm{H}_{2} \mathrm{O}_{2}$ generation on site. The experiments were performed at constant $j$ provided by an EG\&G Princeton Applied Research 273A potentiostat-galvanostat. The surfaces of the anode and cathode were initially cleaned and activated, respectively, under polarization in $100 \mathrm{~mL}$ of $0.050 \mathrm{M} \mathrm{Na}_{2} \mathrm{SO}_{4}$ at $100 \mathrm{~mA} \mathrm{~cm}^{-2}$ for $180 \mathrm{~min}$. Aqueous solutions with $0.21-2.06 \mathrm{mM} \mathrm{4-}$ hydroxyphenylacetic acid and $0.050 \mathrm{M} \mathrm{Na}_{2} \mathrm{SO}_{4}$ at $\mathrm{pH} 3.0$ were treated by $\mathrm{AO}-\mathrm{H}_{2} \mathrm{O}_{2}$ at $j$ values between 16.7 and $100 \mathrm{~mA} \mathrm{~cm}{ }^{-2}$.

\subsection{Analytical Methods}

The solution pH was measured with a Crison GLP 22 pH-meter. For total organic carbon (TOC) determinations, samples were withdrawn from treated solutions, filtered with $0.45 \mu \mathrm{m}$ PTFE filters from Whatman and directly injected into a Shimadzu VCSN TOC analyzer. Reproducible values with $\pm 1 \%$ accuracy were always found.

Assuming the following total mineralization for 4-hydroxyphenylacetic acid:

$\mathrm{C}_{8} \mathrm{H}_{8} \mathrm{O}_{3}+13 \mathrm{H}_{2} \mathrm{O} \rightarrow 8 \mathrm{CO}_{2}+34 \mathrm{H}^{+}+34 \mathrm{e}^{-}$.

the MCE values for each trial were estimated as follows [26,29]:

$\operatorname{MCE}(\%)=\frac{n F V \Delta(\mathrm{TOC})_{\exp }}{4.32 \times 10^{7} \mathrm{mIt}} \times 100$

where $n=34$ is the number of electrons for the mineralization process, as shown in Eq. (4), $F$ is the Faraday constant $\left(96,487 \mathrm{C} \mathrm{mol}^{-1}\right), V$ is the solution volume (L), $\Delta$ (TOC) $)_{\text {exp. }}$ is the experimental TOC decay ( $\mathrm{mg} \mathrm{C} \mathrm{L}^{-1}$ ), $4.32 \times 10^{7}$ is a conversion factor to homogenize the units ( $3600 \mathrm{~s} \mathrm{~h}^{-1} \times 12,000 \mathrm{mg} \mathrm{C} \mathrm{mol}^{-1}$ ), $m=8$ is the number of carbon atoms of 4-hydroxyphenylacetic acid, $I$ is the applied current (A) and $t$ is the electrolysis time $(\mathrm{h})$.

The specific energy consumption per unit TOC mass ( $\mathrm{EC}_{\mathrm{TOC}}$ ) was estimated from Eq. (6) [29,43]:

$\mathrm{EC}_{\mathrm{TOC}}\left(\mathrm{kWh}(\mathrm{gTOC})^{-1}\right)=\frac{\mathrm{E}_{\text {cell }} \mathrm{It}}{\mathrm{V} \Delta(\mathrm{TOC})_{\exp }}$

where $E_{\text {cell }}$ is the average cell voltage (in $V$ ) and the rest of parameters have been defined above.

The 4-hydroxyphenylacetic acid abatement was followed by reversed-phase HPLC using a Waters 600 LC fitted with a BDS Hypersil $\mathrm{C} 186 \mu \mathrm{m}, 250 \mathrm{~mm} \times 4.6 \mathrm{~mm}$, column at $35^{\circ} \mathrm{C}$ and coupled to a Waters 996 photodiode array detector selected at $\lambda=277.0 \mathrm{~nm}$. Measurements were made by injecting $10 \mu \mathrm{L}$ aliquots into the $\mathrm{LC}$ and eluting an acetonitrile/water $(60: 40)$ mixture at $0.6 \mathrm{~mL} \mathrm{~min}^{-1}$ as mobile phase. The chromatograms exhibited a well-defined peak at retention time $\left(t_{\mathrm{r}}\right)$ of $5.0 \mathrm{~min}$. Generated carboxylic acids were identified by ionexclusion HPLC using the same LC fitted with a Bio-Rad Aminex HPX $87 \mathrm{H}, 300 \mathrm{~mm} \times 7.8 \mathrm{~mm}$, column at $35^{\circ} \mathrm{C}$ and the photodiode array detector selected at $\lambda=210.0 \mathrm{~nm}$. Aliquots of $10 \mu \mathrm{L}$ were also injected into the $\mathrm{LC}$ and the mobile phase was $4 \mathrm{mM} \mathrm{H}_{2} \mathrm{SO}_{4}$ at $0.6 \mathrm{~mL} \mathrm{~min}^{-1}$. The chromatograms displayed a well-defined peak related to oxalic acid at $t_{\mathrm{r}}=7.0 \mathrm{~min}$.

The organic products generated upon treatment of $1.03 \mathrm{mM} \mathrm{4-}$ hydroxyphenylacetic acid solutions at 30 and 90 min of $\mathrm{AO}-\mathrm{H}_{2} \mathrm{O}_{2}$ at $33.3 \mathrm{~mA} \mathrm{~cm}^{-2}$ were identified by GC-MS using a NIST05-MS library to 


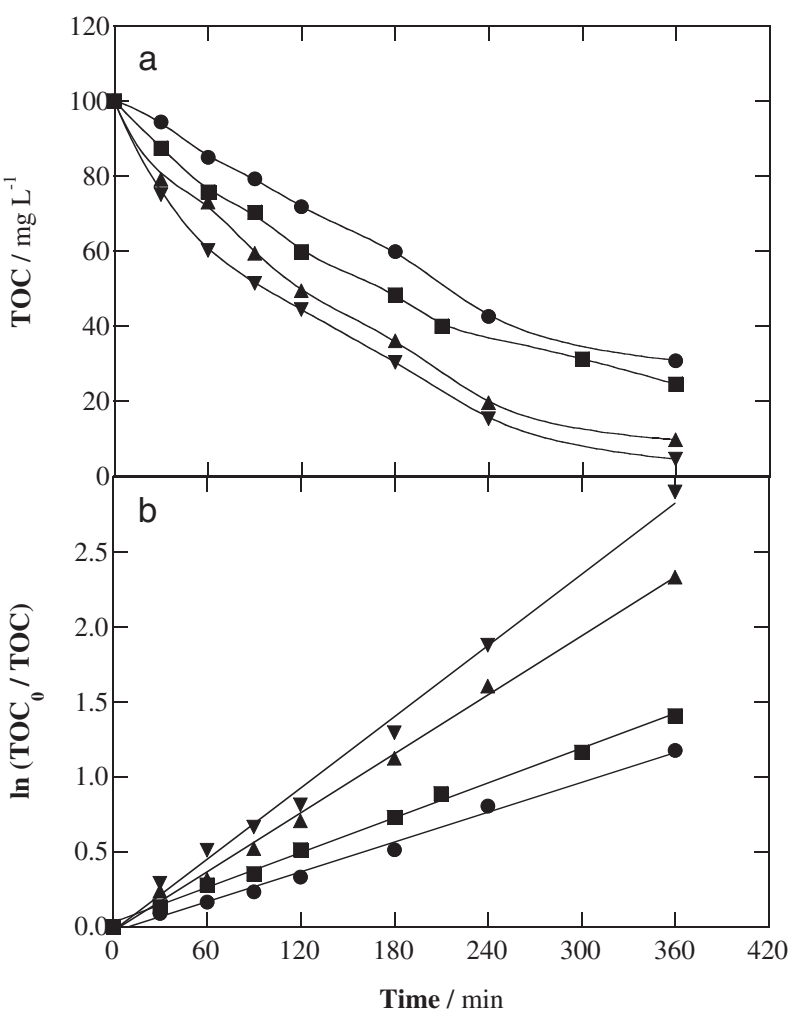

Fig. 1. (a) Effect of current density on TOC removal with electrolysis time for the treatment of $100 \mathrm{~mL}$ of a $1.03 \mathrm{mM}$ 4-hydroxyphenylacetic acid solution in $0.050 \mathrm{M} \mathrm{Na}_{2} \mathrm{SO}_{4}$ at pH 3.0 and $35{ }^{\circ} \mathrm{C}$ by anodic oxidation with electrogenerated $\mathrm{H}_{2} \mathrm{O}_{2}\left(\mathrm{AO}-\mathrm{H}_{2} \mathrm{O}_{2}\right)$ using a stirred tank reactor with a $3 \mathrm{~cm}^{2} \mathrm{BDD}$ anode and a $3 \mathrm{~cm}^{2}$ air-diffusion cathode. (b) Kinetic analysis for TOC removal assuming a pseudo-first-order decay. Applied current density: $(\bullet)$

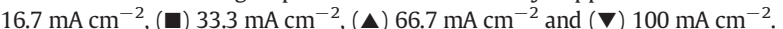

interpret the mass spectra. About 100-250 mL aliquots were lyophilized or extracted out with $\mathrm{CH}_{2} \mathrm{Cl}_{2}(3 \times 25 \mathrm{~mL})$. After lyophilization, the residue was dissolved in $1 \mathrm{~mL}$ of ethyl acetate, whereas after $\mathrm{CH}_{2} \mathrm{Cl}_{2}$ extraction, the organic volume was reduced to about $1 \mathrm{~mL}$ after drying over anhydrous $\mathrm{Na}_{2} \mathrm{SO}_{4}$ followed by filtration. GC-MS analysis of concentrated samples was carried out on an Agilent system composed of a $6890 \mathrm{~N}$ GC and a 5975C MS, operating in EI mode at $70 \mathrm{eV}$. The GC was fitted with either a non-polar Teknokroma Sapiens-X5ms or a polar HP INNOWax column, both of $0.25 \mu \mathrm{m}, 30 \mathrm{~m} \times 0.25 \mathrm{~mm}$. The temperature ramp was: $36{ }^{\circ} \mathrm{C}$ for $1 \mathrm{~min}, 5{ }^{\circ} \mathrm{C} \mathrm{min}^{-1}$ up to $325^{\circ} \mathrm{C}$ and hold time $10 \mathrm{~min}$. The temperature of the inlet, source and transfer line was 250 , 230 and $300{ }^{\circ} \mathrm{C}$ for the non-polar column and 250,230 and $250{ }^{\circ} \mathrm{C}$ for the polar one.

\section{Results and discussion}

\subsection{Effect of Current Density on the Degradation of 4-Hydroxyphenylacetic} Acid

The current density is a crucial parameter in electrochemical treatments of wastewater because it is expected to determine the amount of oxidant, which is $\mathrm{BDD}(\cdot \mathrm{OH})$ in the present study. To test the oxidation ability of $\mathrm{AO}-\mathrm{H}_{2} \mathrm{O}_{2}$ for the decontamination of 4-hydroxyphenylacetic acid solutions and the influence of $j$ on the degradation rate, a first series of experiments was performed by electrolyzing $100 \mathrm{~mL}$ of solutions containing $1.03 \mathrm{mM}$ of this substrate in $0.050 \mathrm{M} \mathrm{Na}_{2} \mathrm{SO}_{4}$ at pH 3.0 and at $j$ values between 16.7 and $100 \mathrm{~mA} \mathrm{~cm}^{-2}$ for $360 \mathrm{~min}$. This acidic $\mathrm{pH}$ was chosen for two reasons: (i) to oxidize the neutral form of the molecule, thereby ensuring mineralization since it prevents from possible polymerizations at the anode, as observed for phenolate ions under alkaline conditions [16,19], and (ii) to work under conditions that are optimal for other promising EAOPs, like those based on Fenton's reaction chemistry $[12,13]$, which will be comparatively investigated in the near future. In all these trials, the solution $\mathrm{pH}$ remained practically unchanged, becoming slightly more acid up to $2.6-2.7$ probably because of the formation of large quantities of acidic by-products like shortchain aliphatic carboxylic acids [13,29].

Fig. 1a shows the TOC-time plots obtained for the above assays. A progressive TOC abatement when prolonging electrolysis can be observed in all cases, as expected from the effective mineralization of the parent molecule and its by-products caused by physisorbed $\operatorname{BDD}(\cdot \mathrm{OH})$. Moreover, data of Fig. 1 a show that increasing $j$ from 16.7 to $100 \mathrm{~mA} \mathrm{~cm}^{-2}$ yielded a greater TOC decay with the consequent enhancement of the oxidation power of the $\mathrm{AO}-\mathrm{H}_{2} \mathrm{O}_{2}$ process. This tendency can also be deduced from Table 1, where the percentage of TOC removal after 120 and $360 \mathrm{~min}$ of electrolysis is summarized. The highest mineralization with 95.5\% TOC decay was then found for the greatest $j$ of $100 \mathrm{~mA} \mathrm{~cm}^{-2}$, whereas TOC was only reduced by $69.1 \%$ at the lowest $j$ of $16.7 \mathrm{~mA} \mathrm{~cm}^{-2}$. The enhancement of TOC abatement at higher $j$ can be simply explained by the concomitant acceleration of all electrode reactions, giving rise to a greater quantity of the main oxidant $\mathrm{BDD}(\cdot \mathrm{OH})$ from reaction (1), as well as of other weaker oxidants like $\mathrm{H}_{2} \mathrm{O}_{2}$ from reaction (2).

A look to Fig. 1a reveals an exponential TOC decay for all trials, suggesting that the mineralization process obeyed a pseudo-first-order kinetics, since it was limited by a constant low content of generated oxidants and controlled by mass transport of reactants toward the anode. This behavior was corroborated by representing the corresponding $\ln \left(\mathrm{TOC}_{0} / \mathrm{TOC}\right)$ values versus the electrolysis time, yielding good straight lines as presented in Fig. 1b. The slope of these correlations corresponds to the pseudo-first-order rate constant for TOC removal ( $\left.k_{\mathrm{TOC}}\right)$, which acquired growing values of $3.4 \times 10^{-3}, 3.9 \times 10^{-3}, 6.6 \times 10^{-3}$ and $7.9 \times 10^{-3} \mathrm{~min}^{-1}$ for increasing $j$ of $16.7,33.3,66.7$ and $100 \mathrm{~mA} \mathrm{~cm}^{-2}$, respectively. The square of the regression coefficient

Table 1

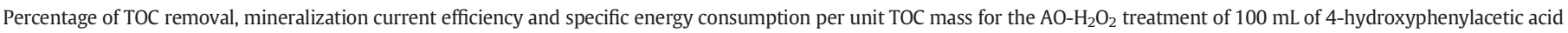
solutions at pH 3.0 using a BDD/air-diffusion cell under selected conditions.

\begin{tabular}{|c|c|c|c|c|c|c|c|}
\hline \multirow[b]{2}{*}{$c_{0}(\mathrm{mM})^{\mathrm{a}}$} & \multirow[b]{2}{*}{$j\left(\mathrm{~mA} \mathrm{~cm}^{-2}\right)^{\mathrm{b}}$} & \multicolumn{3}{|c|}{ After 120 min of electrolysis } & \multicolumn{3}{|c|}{ After $360 \mathrm{~min}$ of electrolysis } \\
\hline & & $\%$ TOC removal & $\% \mathrm{MCE}$ & $\overline{\mathrm{EC}} \mathrm{TOC}\left(\mathrm{kWh}(\mathrm{g} \mathrm{TOC})^{-1}\right)$ & $\%$ TOC removal & $\% \mathrm{MCE}$ & $\mathrm{EC}_{\mathrm{TOC}}\left(\mathrm{kWh}(\mathrm{g} \mathrm{TOC})^{-1}\right)$ \\
\hline 0.21 & 33.3 & 21.5 & 2.05 & 5.89 & 67.6 & 2.15 & 5.62 \\
\hline 0.51 & 33.3 & 35.0 & 8.31 & 1.44 & 82.7 & 6.54 & 1.83 \\
\hline \multirow[t]{4}{*}{1.03} & 16.7 & 28.2 & 26.8 & 0.266 & 69.1 & 21.9 & 0.325 \\
\hline & 33.3 & 40.1 & 19.1 & 0.627 & 75.5 & 11.5 & 1.00 \\
\hline & 66.7 & 50.6 & 12.0 & 1.39 & 90.3 & 7.14 & 2.34 \\
\hline & 100 & 55.6 & 8.79 & 2.46 & 95.5 & 5.04 & 4.30 \\
\hline 2.06 & 33.3 & 24.7 & 23.5 & 0.510 & 64.1 & 20.3 & 0.590 \\
\hline
\end{tabular}

a Initial substrate concentration.

b Current density. 
$\left(R^{2}\right)$ for all these fittings was $>0.99$. From these $k_{\mathrm{Toc}}$ values, one can infer that the apparent rate constant was upgraded only 2.40 -fold when working at 16.7 and $100 \mathrm{~mA} \mathrm{~cm}^{-2}$, respectively (6-fold increase). This is indicative of a loss in process efficiency at greater $j$. This point was confirmed from the MCE values calculated from Eq. (5).

The MCE-time curves related to the experiments shown in Fig. 1a are depicted in Fig. 2a. As can be seen, the current efficiency for the AO$\mathrm{H}_{2} \mathrm{O}_{2}$ degradation of the $1.03 \mathrm{mM}$ 4-hydroxyphenylacetic acid solution underwent a progressive decrease as $j$ increased. This tendency can also be observed in the MCE values after 120 and 360 min of electrolysis given in Table 1. The most efficient process then occurred at the lowest $j$ of $16.7 \mathrm{~mA} \mathrm{~cm}^{-2}$, which reached a maximal of $28.4 \%$ at $60 \mathrm{~min}$ to be further reduced to $21.9 \%$ at the end of treatment. Fig. $2 \mathrm{a}$ also evidences a greater decay of MCE at long electrolysis time when $j$ became higher. This effect can be ascribed to the progressive disappearance of organic matter in solution, as will be discussed below, along with the formation of by-products that are more hardly destroyed by $\operatorname{BDD}(\cdot \mathrm{OH})$. This loss in current efficiency is in contrast to the enhancement of the mineralization rate of 4-hydroxyphenylacetic acid with increasing $j$, and it can be associated with the acceleration of parasitic reactions of $\operatorname{BDD}(\cdot \mathrm{OH})$. This leads to a smaller generation of available amounts of this oxidant, with the consequent waste of current in reactions that do not contribute to the destruction of organics. The most important of such parasitic reactions is the oxidation of $\mathrm{BDD}(\cdot \mathrm{OH})$ to $\mathrm{O}_{2}$ gas via reaction (7), although the dimerization of this radical to $\mathrm{H}_{2} \mathrm{O}_{2}$ from reaction (8) and its destruction by the latter species from reaction (9) can occur as well [13, 21,26,27]. Apart from the partial destruction of the excess of $\operatorname{BDD}(\cdot \mathrm{OH})$ produced at higher $j$ under the action of reactions (7)-(9), the larger production of other weaker oxidants at the BDD anode like
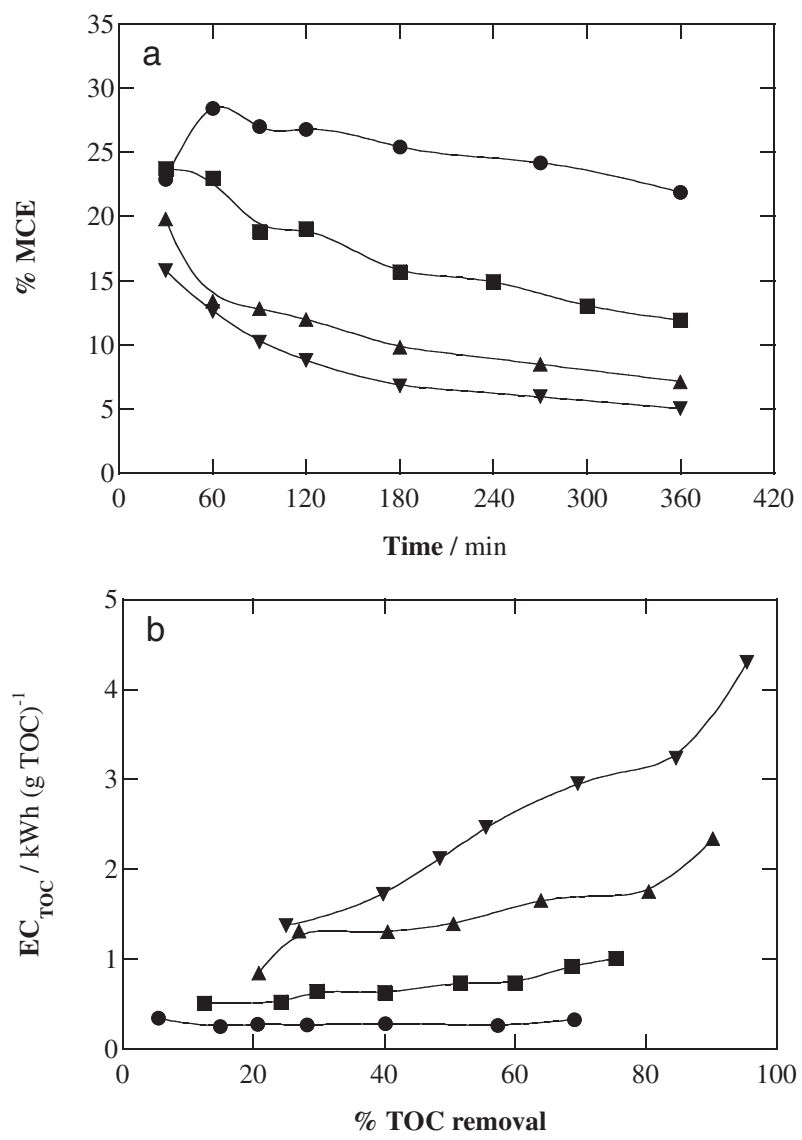

Fig. 2. (a) Mineralization current efficiency vs. electrolysis time and (b) specific energy consumption per unit TOC mass vs. percentage of TOC removal for the trials of Fig. 1. the peroxodisulfate $\left(\mathrm{S}_{2} \mathrm{O}_{8}^{2-}\right)$ ion from the oxidation of $\mathrm{SO}_{4}^{2-}$ ion from the electrolyte via reaction (10) and ozone via reaction (11) also reduces the oxidation power of the $\mathrm{AO}-\mathrm{H}_{2} \mathrm{O}_{2}$ process $[12,16,18]$.

$$
\begin{aligned}
& 2 \mathrm{BDD}(\cdot \mathrm{OH}) \rightarrow 2 \mathrm{BDD}+\mathrm{O}_{2}+2 \mathrm{H}^{+}+2 \mathrm{e}^{-} \\
& 2 \mathrm{BDD}(\cdot \mathrm{OH}) \rightarrow 2 \mathrm{BDD}+\mathrm{H}_{2} \mathrm{O}_{2} \\
& \mathrm{H}_{2} \mathrm{O}_{2}+\mathrm{BDD}(\cdot \mathrm{OH}) \rightarrow \mathrm{BDD}\left(\mathrm{HO}_{2} \bullet\right)+\mathrm{H}_{2} \mathrm{O} \\
& 2 \mathrm{SO}_{4}{ }^{2-} \rightarrow \mathrm{S}_{2} \mathrm{O}_{8}{ }^{2-}+2 \mathrm{e}^{-} \\
& 3 \mathrm{H}_{2} \mathrm{O} \rightarrow \mathrm{O}_{3}+6 \mathrm{H}^{+}+6 \mathrm{e}^{-}
\end{aligned}
$$

The $\mathrm{EC}_{\mathrm{TOC}}$ is another key parameter to characterize the viability of AO- $\mathrm{H}_{2} \mathrm{O}_{2}$ for 4-hydroxyphenylacetic acid degradation since cost-effective processes are needed for practical application. For the above trials, Fig. 2b highlights the expected rise in $\mathrm{EC}_{\mathrm{TOC}}$ determined from Eq. (6) when $j$ increased, as a result of the concomitant growth of $E_{\text {cell. }}$. Results of Table 1 also evidence that the specific energy consumption remained practically constant at $j=16.7 \mathrm{~mA} \mathrm{~cm}{ }^{-2}$, slightly increasing with electrolysis time at $j=33.3 \mathrm{~mA} \mathrm{~cm}{ }^{-2}$ and undergoing a much larger increase at 66.7 and $100 \mathrm{~mA} \mathrm{~cm}^{-2}$. At this latter $j$, the final $\mathrm{EC}_{\mathrm{TOC}}$ value was as high as $4.30 \mathrm{kWh}(\mathrm{g} \mathrm{TOC})^{-1}$, in contrast to $0.325 \mathrm{kWh}$ $(\mathrm{g} \mathrm{TOC})^{-1}$ found at $j=16.7 \mathrm{~mA} \mathrm{~cm}^{-2}$.

The aforementioned findings demonstrate that the use of low $j$ values is preferable for the $\mathrm{AO}-\mathrm{H}_{2} \mathrm{O}_{2}$ degradation of the $1.03 \mathrm{mM} 4-$ hydroxyphenylacetic acid solution tested, although lower mineralization was achieved compared to that at high $j$ values. Since in Spain the price of the industrial electrical energy is $0.092 €(\mathrm{kWh})^{-1}$ on average, the cost of the cheapest treatment after $360 \mathrm{~min}$ at the lowest $j$ of $16.7 \mathrm{~mA} \mathrm{~cm}^{-2}$ would be around $0.030 €(\mathrm{~g} \mathrm{TOC})^{-1}$, achieving a mineralization of $69.1 \%$ with the greatest current efficiency of $29.1 \%$.

\subsection{Influence of 4-Hydroxyphenylacetic Acid Concentration on Its Degradation Process}

The substrate concentration is an important operation variable that affects the rate of the attack of generated oxidants on organic molecules, which competes with parasitic reactions. The influence of this parameter on the degradation rate for the $\mathrm{AO}-\mathrm{H}_{2} \mathrm{O}_{2}$ treatment of $100 \mathrm{~mL}$ of 4hydroxyphenylacetic acid solutions in $0.050 \mathrm{M} \mathrm{Na}_{2} \mathrm{SO}_{4}$ at pH 3.0 using a BDD anode was examined for concentrations between 0.21 and $2.06 \mathrm{mM}$ by applying a $j=33.3 \mathrm{~mA} \mathrm{~cm}{ }^{-2}$ for $360 \mathrm{~min}$. No significant $\mathrm{pH}$ change was observed during these trials, since its value only decreased to 2.6-2.7 due to the formation of acidic by-products, as pointed out above.

Fig. 3a depicts the TOC decay determined for these assays versus the electrolysis time and Table 1 summarizes the percentage of TOC removal at selected times of 120 and 360 min. Different degradation rates can be observed depending on substrate content despite that the same quantity of $\operatorname{BDD}(\cdot \mathrm{OH})$ was always expected to be generated from reaction (1) at $j=33.3 \mathrm{~mA} \mathrm{~cm}^{-2}$. For the lowest content $(0.21 \mathrm{mM})$, the solution was very poorly degraded, especially at the beginning of the process, and its TOC was only reduced by $67.6 \%$ after $360 \mathrm{~min}$. This suggests a large influence of parasitic reactions (7)-(9), significantly diminishing the amount of $\operatorname{BDD}(\cdot \mathrm{OH})$ that is available to react with the low quantity of organic matter present in solution. In contrast, when the concentration was increased to $0.51 \mathrm{mM}$, the percentage of TOC decay was strongly upgraded (see Table 1 ), indicating a more effective mineralization of organics by $\operatorname{BDD}(\cdot \mathrm{OH})$ as a result of the deceleration of reactions (7)-(9). Further treatment of more concentrated solutions up to $2.06 \mathrm{mM}$ caused a progressive drop of the percentage 


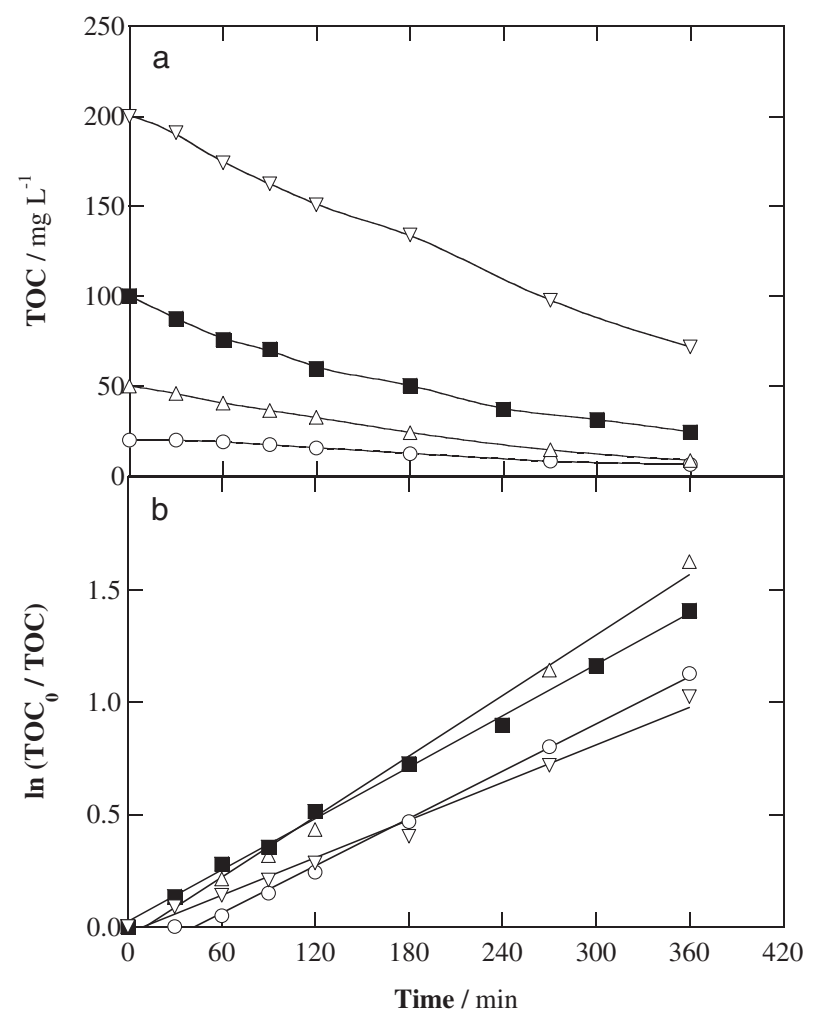

Fig. 3. (a) Influence of pollutant concentration on TOC abatement with electrolysis time for the degradation of $100 \mathrm{~mL}$ of 4-hydroxyphenylacetic acid solutions in $0.050 \mathrm{M} \mathrm{Na}_{2} \mathrm{SO}_{4}$ at pH 3.0 by AO- $\mathrm{H}_{2} \mathrm{O}_{2}$ using a BDD/air-diffusion cell at $33.3 \mathrm{~mA} \mathrm{~cm}{ }^{-2}$ and $35^{\circ} \mathrm{C}$. (b) Analysis for TOC decay assuming a pseudo-first-order kinetics. 4-Hydroxyphenylacetic acid content: $(O) 0.21 \mathrm{mM},(\Delta) 0.51 \mathrm{mM},(\mathbf{\square}) 1.03 \mathrm{mM}$ and $(\nabla) 2.06 \mathrm{mM}$.

of TOC decay, as can be seen in Table 1, although a larger amount of TOC was gradually removed due to the faster oxidation of organics with greater quantities of available $\mathrm{BDD}(\bullet \mathrm{OH})$ thanks to the gradual decay in rate of parasitic reactions (7)-(9).

The good linear correlations related to the pseudo-first-order kinetics of TOC abatement for the experiments of Fig. 3a are depicted in Fig. $3 \mathrm{~b}$. It should be noted that in the case of $0.21 \mathrm{mM}$, the linear trend between $\ln \left(\mathrm{TOC}_{0} / \mathrm{TOC}\right)$ and electrolysis time started from about $60 \mathrm{~min}$ of the $\mathrm{AO}-\mathrm{H}_{2} \mathrm{O}_{2}$ treatment because no significant mineralization was found at shorter time. The $k_{\text {TOC }}$ value under these conditions was $3.5 \times 10^{-3} \mathrm{~min}^{-1}\left(R^{2}=0.996\right)$, which increased to $4.9 \times 10^{-3} \mathrm{~min}^{-1}$ $\left(R^{2}=0.990\right)$ for $0.51 \mathrm{mM}$ due to the larger oxidation action of $\operatorname{BDD}(\cdot \mathrm{OH})$. In contrast, the presence of higher 4-hydroxyphenylacetic acetic concentration caused a gradual drop in $k_{\mathrm{TOc}}$, with values of $3.8 \times 10^{-3} \mathrm{~min}^{-1}\left(R^{2}=0.996\right)$ for $1.03 \mathrm{mM}$ and $2.8 \times 10^{-3} \mathrm{~min}^{-1}$ $\left(R^{2}=0.990\right)$ for $2.06 \mathrm{mM}$, because a lower TOC $_{0} /$ TOC ratio was obtained despite the removal of greater amounts of TOC.

The enhancement of the oxidation power of the $\mathrm{AO}-\mathrm{H}_{2} \mathrm{O}_{2}$ process with increasing substrate concentration at constant $j$ for the above trials can be more easily deduced from the change of the corresponding MCE values. Fig. 4a highlights that the current efficiency underwent a progressive rise as 4-hydroxyphenylacetic acid content grew from 0.21 to $2.06 \mathrm{mM}$. This behavior can be pre-eminently accounted for by the more efficient action of reactive physisorbed $\operatorname{BDD}(\bullet \mathrm{OH})$ due to the deceleration of its parasitic reactions (7)-(9), as stated above. For the most concentrated solution, the MCE value decayed from a maximal value of $24.8 \%$ at $60 \mathrm{~min}$ to $20.3 \%$ at the end of treatment (see Table 1). A drop of current efficiency from $23.7 \%$ at 30 min to $11.9 \%$ at $360 \mathrm{~min}$ was also determined for $1.03 \mathrm{mM}$, whereas it decreased from $9.1 \%$ at $60 \mathrm{~min}$ as maximal to a final value of $6.5 \%$ for $0.51 \mathrm{mM}$. In contrast, an MCE value near 2.1\% was found for $0.21 \mathrm{mM}$ (see Table 1). These findings corroborate that the decay in current efficiency when
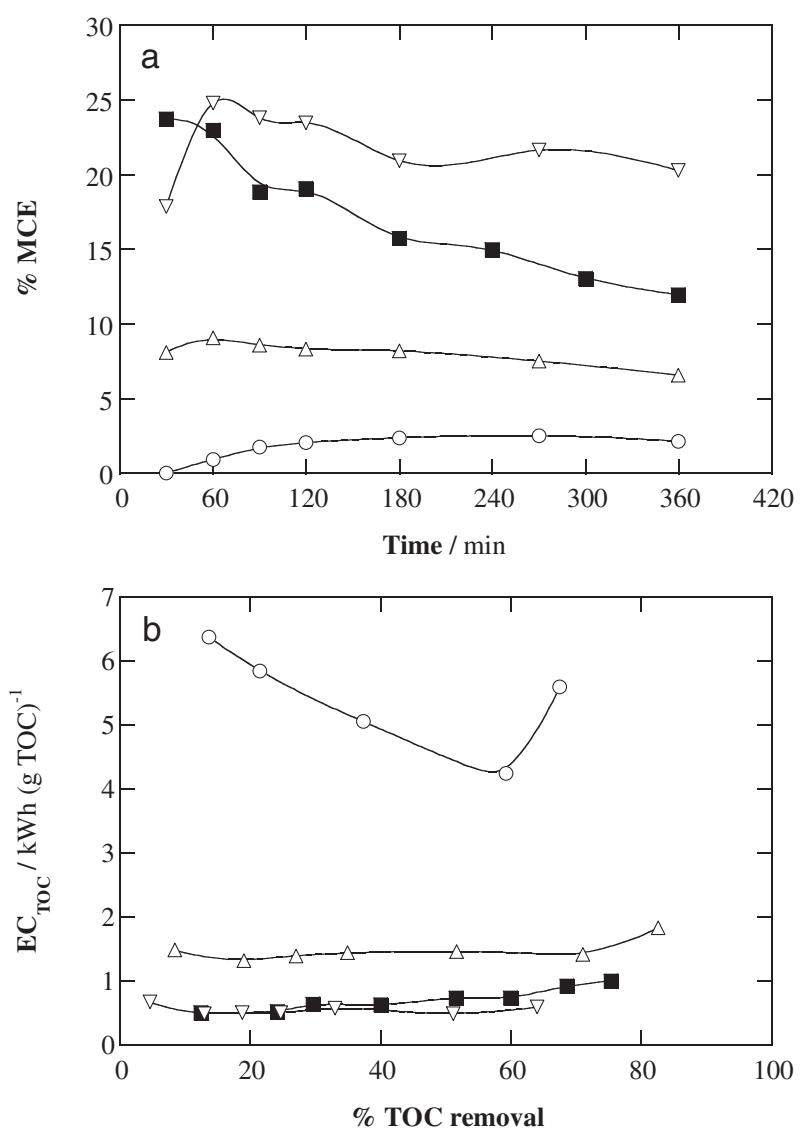

Fig. 4. (a) Time course of mineralization current efficiency and (b) variation of specific energy consumption per unit TOC mass with percentage of TOC removal for the assays of Fig. 3.

prolonging the electrolysis for substrate concentrations $\geq 0.51 \mathrm{mM}$, shown in Fig. 2a and 4a, is mainly due to the loss of organic matter in solution, although it can be influenced by the gradual formation of more recalcitrant products that makes the degradation process slower.

The very small oxidation power of $\mathrm{AO}-\mathrm{H}_{2} \mathrm{O}_{2}$ to mineralize the solution of $0.21 \mathrm{mM}$ 4-hydroxyphenylacetic acid was also reflected in the very high $\mathrm{EC}_{\mathrm{TOC}}$ values required, ranging between 4.3 and $6.4 \mathrm{kWh}$ $(\mathrm{g} \mathrm{TOC})^{-1}$, to attain $67.6 \%$ of TOC removal, as can be seen in Fig. $4 \mathrm{~b}$. This figure, as well as the data collected in Table 1, shows a gradual reduction of the specific energy consumption when going up to the maximum content of $2.06 \mathrm{mM}$, which led to a final value of $0.590 \mathrm{kWh}$ (g TOC $)^{-1}$ to remove $64.1 \%$ of TOC. These results allow concluding that higher substrate contents are preferable to be mineralized by AO$\mathrm{H}_{2} \mathrm{O}_{2}$ since they lead to greater MCE and lower $\mathrm{EC}_{\mathrm{TOC}}$ values, but with smaller mineralization of treated solutions.

\subsection{Decay Kinetics of 4-Hydroxyphenylacetic Acid}

The kinetics of the reaction between 4-hydroxyphenylacetic acid and generated $\operatorname{BDD}(\cdot \mathrm{OH})$ was followed by reversed-phase HPLC, where this compound presented a well-defined peak. Fig. 5a illustrates the exponential concentration decay for a $1.03 \mathrm{mM}$ substrate solution in $0.050 \mathrm{M} \mathrm{Na}_{2} \mathrm{SO}_{4}$ at $\mathrm{pH} 3.0$ treated by $\mathrm{AO}-\mathrm{H}_{2} \mathrm{O}_{2}$ with a BDD anode at $j=$ $33.3 \mathrm{~mA} \mathrm{~cm} \mathrm{~cm}^{-2}$. Total removal was achieved after approximately 360 min of electrolysis, meaning that the $24.5 \%$ of the initial TOC remaining in solution at that time (see Fig. 1a) is due to the accumulated by-products, which are more recalcitrant than the parent molecule. The drop of substrate concentration was well-fitted to a pseudo-first-order kinetic equation, as shown in Fig. 5b. A pseudo-first-order rate constant 

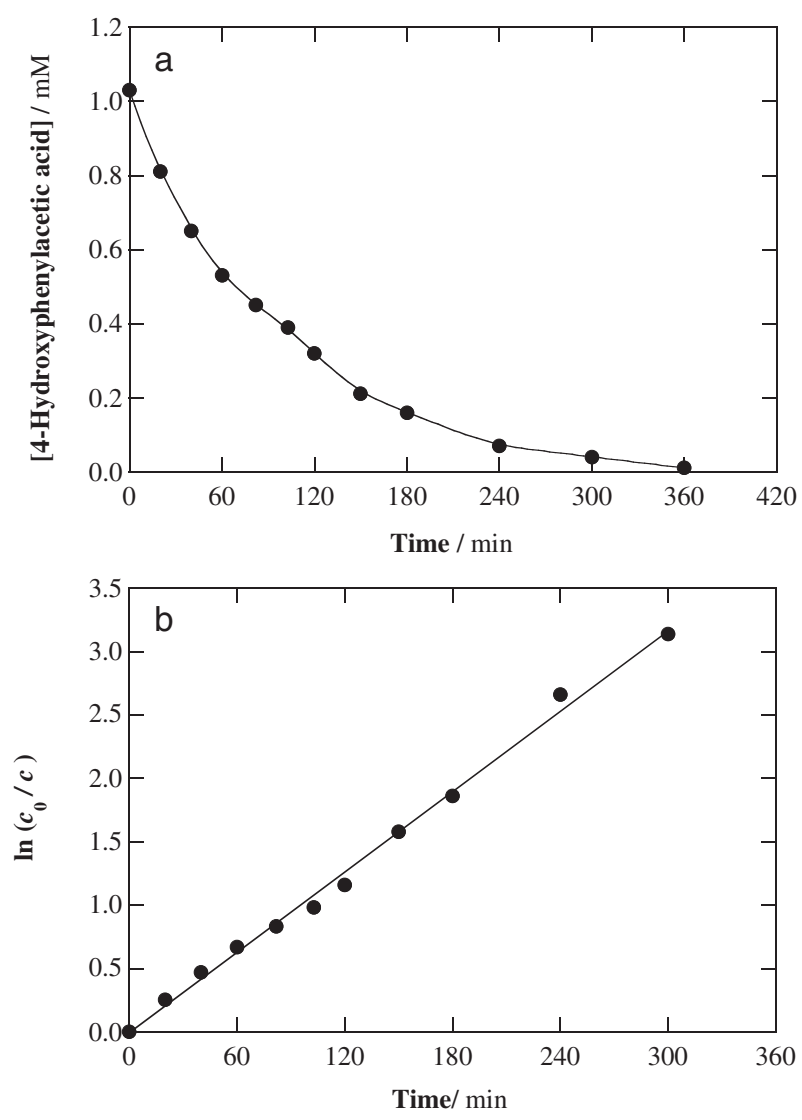

Fig. 5. (a) Decay of 4-hydroxyphenylacetic acid concentration with electrolysis time for the degradation of $100 \mathrm{~mL}$ of a $1.03 \mathrm{mM}$ pollutant solution in $0.050 \mathrm{M} \mathrm{Na}_{2} \mathrm{SO}_{4}$ at pH 3.0 and $35{ }^{\circ} \mathrm{C}$ by $\mathrm{AO}-\mathrm{H}_{2} \mathrm{O}_{2}$ using a BDD/air-diffusion cell at $33.3 \mathrm{~mA} \mathrm{~cm}^{-2}$. (b) Kinetic analysis assuming a pseudo-first-order reaction for 4-hydroxyphenylacetic acid.

( $\left.k_{1}\right)$ of $1.0 \times 10^{-2} \mathrm{~min}^{-1}$, with $R^{2}=0.995$, was then determined as slope of the excellent linear trend obtained.

The aforementioned behavior suggests the attack of a constant $\mathrm{BDD}(\cdot \mathrm{OH})$ concentration on 4-hydroxyphenylacetic acid. This is feasible by the short lifetime of this radical $\left(\approx 10^{-9} \mathrm{~s}[13]\right)$ that allows the presence of a very small steady-state concentration during the AO$\mathrm{H}_{2} \mathrm{O}_{2}$ process. Accordingly, the reaction rate $(r)$ between $\mathrm{BDD}(\cdot \mathrm{OH})$ and the molecule obeys a second-order kinetics, expressed as follows:

$$
r=k_{2}[\mathrm{BDD}(\cdot \mathrm{OH})][R]=k_{1}[R]
$$

where $k_{2}\left(=k_{1} /[\mathrm{BDD}(\cdot \mathrm{OH})]\right)$ is the absolute or second-order rate constant and $\mathrm{R}$ symbolizes the 4-hydroxyphenylacetic acid tested. Taking into account that a $k_{2}$ value of $7.02 \times 10^{8} \mathrm{M}^{-1} \mathrm{~s}^{-1}$ has been determined for this reaction [11], one can estimate the generation of an average $\operatorname{BDD}(\cdot \mathrm{OH})$ concentration $\left(=k_{1} / k_{2}\right)$ of near $2.4 \times 10^{-13} \mathrm{M}$. This radical is expected to act within a small volume near the anode surface owing to its very low adsorption on BDD [16].

\subsection{Identification and Evolution of By-products}

Table 2 collects the organic products detected by GC-MS for short electrolysis times during the $\mathrm{AO}-\mathrm{H}_{2} \mathrm{O}_{2}$ treatment of a $1.03 \mathrm{mM} \mathrm{4-}$ hydroxyphenylacetic acid solution at $\mathrm{pH} 3.0$ with a BDD anode. Apart from the parent molecule, two primary aromatic by-products (4hydroxybenzenemethanol and 4-hydroxybenzaldehyde) and one final aliphatic carboxylic acid (acetic acid) were identified by means of this technique. One can then establish that the initial attack of $\operatorname{BDD}(\cdot \mathrm{OH})$ yields the decarboxylation with hydroxylation of 4-hydroxyphenylacetic acid to produce the diol 4-hydroxybenzenemethanol, which is in turn oxidized to 4-hydroxybenzaldehyde. On the other hand, acetic acid is a final aliphatic carboxylic acid that proceeds from the oxidation of aromatic intermediates with cleavage of their benzenic ring [12,29,39].

The evolution of final carboxylic acids was also followed by ion-exclusion HPLC. These chromatograms only displayed traces of acetic acid $(<0.001 \mathrm{mM})$, the final by-product identified by GC-MS, at $t_{\mathrm{r}}=$ $14.9 \mathrm{~min}$. In contrast, they revealed the presence of great amounts of oxalic acid, a usual final aliphatic carboxylic acid that can be directly transformed into $\mathrm{CO}_{2}[21,26,33]$. Fig. 6 depicts the time course of oxalic acid concentration during the $\mathrm{AO}-\mathrm{H}_{2} \mathrm{O}_{2}$ degradation of a $1.03 \mathrm{mM} 4-$ hydroxyphenylacetic acid solution at $j=33.3 \mathrm{~mA} \mathrm{~cm}^{-2}$. As can be seen, it was progressively accumulated up to a maximum concentration of $0.16 \mathrm{mM}$ at $180-240 \mathrm{~min}$, further being slowly removed to $0.071 \mathrm{mM}$ at the end of th electrolysis. A simple mass balance highlights that this acid content corresponds to $1.70 \mathrm{mg} \mathrm{L}^{-1}$ of TOC, which only accounts for $6.9 \%$ of the total TOC of the remaining solution (see Fig. 1a). This

Table 2

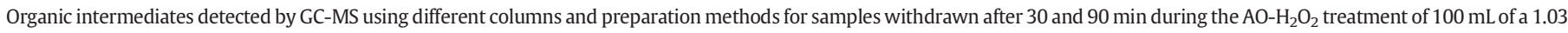
$\mathrm{mM}$ 4-hydroxyphenylacetic acid solution in $0.050 \mathrm{M} \mathrm{Na}_{2} \mathrm{SO}_{4}$ at $\mathrm{pH} 3.0$ using a BDD/air-diffusion cell at $33.3 \mathrm{~mA} \mathrm{~cm}^{-2} \mathrm{and}_{35}^{\circ} \mathrm{C}$.

\begin{tabular}{|c|c|c|c|c|c|}
\hline Compound & Molecular structure & Electrolysis time (min) & Column & $t_{\mathrm{r}}^{\mathrm{a}}(\min )$ & Main fragmentation ions $(\mathrm{m} / \mathrm{z})$ \\
\hline 4-Hydroxyphenylacetic acid & & $\begin{array}{l}30^{\mathrm{b}} \\
30^{\mathrm{b}}, 30^{\mathrm{c}}\end{array}$ & $\begin{array}{l}\text { Polar } \\
\text { Non-polar }\end{array}$ & $\begin{array}{l}63.7 \\
26.3\end{array}$ & $152,107,77$ \\
\hline 4-Hydroxybenzenemethanol & & $30^{c}$ & Non-polar & 20.9 & $124,107,95,77$ \\
\hline 4-Hydroxybenzaldehyde & & $\begin{array}{l}30^{\mathrm{b}}, 90^{\mathrm{c}} \\
30^{\mathrm{c}}, 90^{\mathrm{c}}\end{array}$ & $\begin{array}{l}\text { Polar } \\
\text { Non-polar }\end{array}$ & $\begin{array}{l}43.3 \\
21.4\end{array}$ & $121,93,65$ \\
\hline Acetic acid & & $30^{\mathrm{b}}$ & Polar & 15.3 & 60,43 \\
\hline
\end{tabular}

a Retention time.

b Lyophilized sample.

c Extraction with $\mathrm{CH}_{2} \mathrm{Cl}_{2}$. 


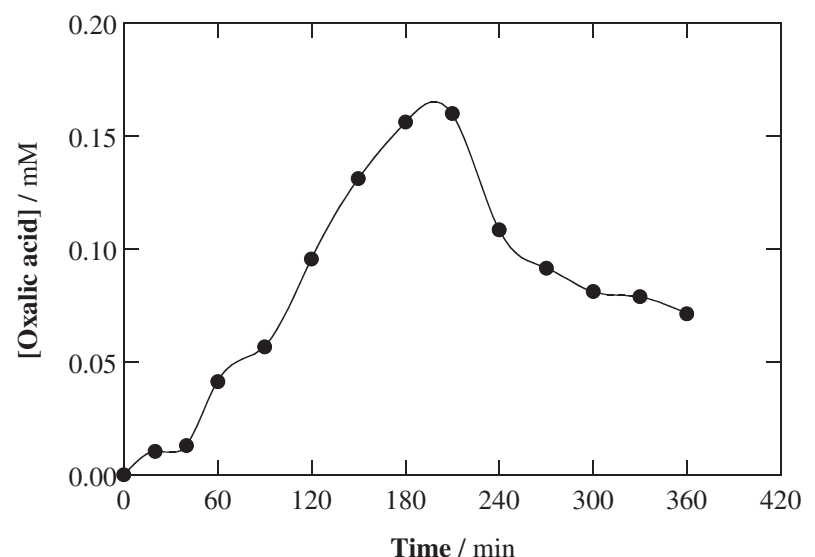

Fig. 6. Evolution of the concentration of oxalic acid detected during the $\mathrm{AO}-\mathrm{H}_{2} \mathrm{O}_{2}$ treatment shown in Fig. 5.

means that the final solution contained a large proportion of unidentified products that are even more hardly oxidized by $\operatorname{BDD}(\bullet \mathrm{OH})$ than final aliphatic carboxylic acids.

\section{Conclusions}

It has been shown that $100 \mathrm{~mL}$ of a $1.03 \mathrm{mM}$ 4-hydroxyphenylacetic acid solution in sulfate medium at $\mathrm{pH} 3.0$ can be almost totally mineralized upon $\mathrm{AO}-\mathrm{H}_{2} \mathrm{O}_{2}$ treatment with a $\mathrm{BDD} /$ air-diffusion cell. The use of a lower $j$ yielded a lower mineralization, but the process was more costeffective. The best results were found at $j=16.7 \mathrm{~mA} \mathrm{~cm}^{-2}$, leading to $21.9 \%$ of current efficiency with $0.325 \mathrm{kWh}(\mathrm{g} \text { TOC })^{-1}$, but with only $67.6 \%$ of TOC removal. The efficiency of the process was upgraded and the specific energy consumption became lower when the substrate concentration was increased, although a smaller mineralization was attained. The oxidation role of $\operatorname{BDD}(\cdot \mathrm{OH})$ was then a function of its electrogeneration rate at the anode, governed by $j$, and the extent of its parasitic reactions. TOC removal and substrate concentration decay obeyed a pseudo-first-order kinetics since they were limited by the amount of reactive $\mathrm{BDD}(\cdot \mathrm{OH})$ and the mass transport of organics toward the BDD anode. 4-Hydroxybenzenemethanol and its oxidation product 4-hydroxybenzenealdehyde were found as primary aromatic by-products. Ion-exclusion chromatograms revealed the accumulation of low contents of oxalic acid that persist during all the process, highlighting that the final treated solutions contained a large proportion of unidentified, recalcitrant by-products.

\section{Acknowledgements}

Financial support from project CTQ2013-48897-C2-1-R (MINECO, FEDER, EU) and the PhD fellowship awarded to N. Flores by SENESCYT (Ecuador) are acknowledged.

\section{References}

[1] S. Magdich, C. Ben Ahmed, R. Jarboui, B. Ben Rouina, M. Boukhris, E. Ammar, Dose and frequency dependent effects of olive mill wastewater treatment on the chemical and microbial properties of soil, Chemosphere 93 (2013) 1896-1903.

[2] S. Dermeche, M. Nadour, C. Larroche, F. Moulti-Mati, P. Michaud, Olive mill wastes: biochemical characterizations and valorization strategies, Process Biochem. 48 (2013) 1532-1552.

[3] M. DellaGreca, L. Previtera, F. Temussi, A. Zarrelli, Low-molecular-weight components of olive oil mill waste-waters, Phytochem. Anal. 15 (2004) 184-188.

[4] J.M. Ochando-Pulido, M.D. Victor-Ortega, G. Hodaifa, A. Martinez-Ferez, Physicochemical analysis and adequation of olive oil mill wastewater after advanced oxidation process for reclamation by pressure-driven membrane technology, Sci. Total Environ. 503-504 (2014) 113-121.

[5] D. Pham Minh, P. Gallezot, S. Azabou, S. Sayadi, M. Besson, Catalytic wet air oxidation of olive oil mill effluents, Appl. Catal. B Environ. 84 (2008) 749-757.
[6] C. Belaid, M. Kallel, M. Khadhraou, G. Lalleve, B. Elleuch, J.F. Fauvarque, Electrochemical treatment of olive mill wastewaters: removal of phenolic compounds and decolourization, J. Appl. Electrochem. 36 (2006) 1175-1182.

[7] C. Belaid, M. Khadraoui, S. Mseddi, M. Kallel, B. Elleuch, J.F. Fauvarque, Electrochemical treatment of olive mill wastewater: treatment extent and effluent phenolic compounds monitoring using some uncommon analytical tools, J. Environ. Sci. 25 (2013) 220-230.

[8] P.P. Liebgott, M. Labat, A. Amouric, J.L. Tholozan, J. Lorquin, Tyrosol degradation via the homogentisic acid pathway in a newly isolated Halomonas strain from olive processing effluents, J. Appl. Microbiol. 105 (2008) 2084-2095.

[9] S. Ammar, M.A. Oturan, L. Labiadh, A. Guersalli, R. Abdelhedi, N. Oturan, E. Brillas, Degradation of tyrosol by a novel electro-Fenton process using pyrite as heterogeneous source of iron catalyst, Water Res. 74 (2015) 77-87.

[10] I. Sanchez, F. Stueber, A. Fabregat, J. Font, A. Fortuny, C. Bengoa, Degradation of model olive mill contaminants of OMW catalysed by zero-valent iron enhanced with a chelant, J. Hazard. Mater. 199-200 (2012) 328-335.

[11] F.J. Benitez, J.L. Acero, F.J. Real, F.J. Rubio, A. Leal, The role of hydroxyl radicals for the decomposition of p-hydroxy phenylacetic acid in aqueous solutions, Water Res. 35 (2001) 1338-1343.

[12] I. Sirés, E. Brillas, Remediation of water pollution caused by pharmaceutical residues based on electrochemical separation and degradation technologies: a review, Environ. Int. 40 (2012) 212-229.

[13] I. Sirés, E. Brillas, M.A. Oturan, M.A. Rodrigo, M. Panizza, Electrochemical advanced oxidation processes: today and tomorrow. A review, Environ. Sci. Pollut. Res. 21 (2014) 8336-8367.

[14] A. Thiam, I. Sirés, J.A. Garrido, R.M. Rodríguez, E. Brillas, Decolorization and mineralization of Allura Red AC aqueous solutions by electrochemical advanced oxidation processes, J. Hazard. Mater. 290 (2015) 34-42.

[15] A. Thiam, I. Sirés, F. Centellas, P.L. Cabot, E. Brillas, Decolorization and mineralization of Allura Red AC azo dye by solar photoelectro-Fenton: identification of intermediates, Chemosphere 136 (2015) 1-8.

[16] M. Panizza, G. Cerisola, Direct and mediated anodic oxidation of organic pollutants, Chem. Rev. 109 (2009) 6541-6569.

[17] S. Vasudevan, M.A. Oturan, Electrochemistry: as cause and cure in water pollutionan overview, Environ. Chem. Lett. 12 (2014) 97-108.

[18] B. Boye, P.A. Michaud, B. Marselli, M.M. Dieng. E. Brillas, C. Comninellis, Anodic oxidation of 4-chlorophenoxyacetic acid on synthetic boron-doped diamond electrodes, New Diamond Front. Carbon Technol. 12 (2002) 63-72.

[19] B. Marselli, J. Garcia-Gomez, P.A. Michaud, M.A. Rodrigo, C. Comninellis, Electrogeneration of hydroxyl radicals on boron-doped diamond electrodes, J. Electrochem. Soc. 150 (2003) D79-D83.

[20] P. Cañizares, J. Lobato, R. Paz, M.A. Rodrigo, C. Saez, Electrochemical oxidation of phenolic compound wastes with BDD anodes, Water Res. 39 (2005) 2687-2703.

[21] E. Brillas, I. Sirés, C. Arias, P.L. Cabot, F. Centellas, R.M. Rodríguez, J.A. Garrido, Mineralization of paracetamol in aqueous medium by anodic oxidation with a borondoped diamond electrode, Chemosphere 58 (2005) 399-406.

[22] A. Özcan, Y. Sahin, A.S. Koparal, M.A. Oturan, Propham mineralization in aqueous medium by anodic oxidation using boron-doped diamond anode. Experimental parameters' influence on degradation kinetics and mineralization efficiency, Water Res, 42 (2008) 2889-2898.

[23] V. Santos, J. Diogo, M.J.A. Pacheco, L. Ciríaco, A. Morão, A. Lopes, Electrochemical degradation of sulfonated amines on Si/BDD electrodes, Chemosphere 79 (2010) 637-645.

[24] M.A. Rodrigo, P. Cañizares, A. Sánchez-Carretero, C. Sáez, Use of conductive-diamond electrochemical oxidation for wastewater treatment, Catal. Today 151 (2010) 173-177.

[25] N. Oturan, E. Brillas, M.A. Oturan, Unprecedented total mineralization of atrazine and cyanuric acid by anodic oxidation and electro-Fenton with a boron-doped diamond anode, Environ. Chem. Lett. 10 (2012) 165-170.

[26] A. El-Ghenymy, J.A. Garrido, R.M. Rodríguez, P.L. Cabot, F. Centellas, C. Arias, E. Brillas, Degradation of sulfanilamide in acidic medium by anodic oxidation with a boron-doped diamond anode, J. Electroanal. Chem. 689 (2013) 149-157.

[27] C.I. Brinzila, N. Monterio, M.J. Pacheco, L. Ciriaco, I. Siminiceanu, A. Lopes, Degradation of tetracycline at a boron-doped diamond anode: influence of initial $\mathrm{pH}$, applied current intensity and electrolyte, Environ. Sci. Pollut. Res. 21 (2014) 8457-8465.

[28] E.V. dos Santos, C. Sáez, C.A. Martínez-Huitle, P. Cañizares, M.A. Rodrigo, The role of particle size on the conductive diamond electrochemical oxidation of soil-washing effluent polluted with atrazine, Electrochem. Commun. 55 (2015) 26-29.

[29] A. Bedolla-Guzman, I. Sirés, A. Thiam, J.M. Peralta-Hernández, S. Gutiérrez-Granados, E. Brillas, Application of anodic oxidation, electro-Fenton and UVA photoelectroFenton to decolorize and mineralize acidic solutions of Reactive Yellow 160 azo dye, Electrochim. Acta 206 (2016) 307-316.

[30] P. Cañizares, R. Paz, C. Sáez, M.A. Rodrigo, Electrochemical oxidation of alcohols and carboxylic acids with diamond anodes. A comparison with other advanced oxidation processes, Electrochim. Acta 53 (2008) 2144-2153.

[31] I. Sirés, P.L. Cabot, F. Centellas, J.A. Garrido, R.M. Rodríguez, C. Arias, E. Brillas, Electrochemical degradation of clofibric acid in water by anodic oxidation. Comparative study with platinum and boron-doped diamond electrodes, Electrochim. Acta 52 (2006) 75-85.

[32] M. Hamza, R. Abdelhedi, E. Brillas, I. Sirés, Comparative electrochemical degradation of the triphenylmethane dye Methyl Violet with boron-doped diamond and Pt anodes, J. Electroanal. Chem. 627 (2009) 41-50.

[33] E.B. Cavalcanti, S. Garcia-Segura, F. Centellas, E. Brillas, Electrochemical incineration of omeprazole in neutral aqueous medium using a platinum or boron-doped diamond. Degradation kinetics and oxidation products, Water Res. 47 (2013) 1803-1815. 
[34] L. Ciríaco, C. Anjo, J. Correia, M.J. Pacheco, A. Lopes, Electrochemical degradation of ibuprofen on Ti/Pt/PbO 2 and $\mathrm{Si} / \mathrm{BDD}$ electrodes, Electrochim. Acta 54 (2009) $1464-1472$.

[35] K. Cruz-González, O. Torres-López, A. García-León, E. Brillas, A. Hernández-Ramírez, J.M. Peralta-Hernández, Optimization of electro-Fenton/BDD process for decolorization of a model azo dye wastewater by means of response surface methodology, Desalination 286 (2012) 63-68.

[36] A. Wang, J. Qu, H. Liu, J. Ru, Mineralization of an azo dye Acid Red 14 by photoelectro-Fenton process using an activated carbon fiber cathode, Appl. Catal. B Environ. 84 (2008) 393-399.

[37] A. Khataee, A. Akbarpour, B. Vahi, Photoassisted electrochemical degradation of an azo dye using $\mathrm{Ti} / \mathrm{RuO}_{2}$ anode and carbon nanotubes containing gas-diffusion cathode, J. Taiwan Inst. Chem. Eng. 45 (2014) 930-936.

[38] N. Daneshvar, S. Aber, V. Vatanpour, M.H. Rasoulifard, Electro-Fenton treatment of dye solution containing Orange II: influence of operational parameters, J. Electroanal. Chem. 615 (2008) 165-174.

[39] A. Dirany, I. Sirés, N. Oturan, A. Özcan, M.A. Oturan, Electrochemical treatment of the antibiotic sulfachloropyridazine: kinetics, reaction pathways, and toxicity evolution, Environ. Sci. Technol. 46 (2012) 4074-4082.
[40] A. El-Ghenymy, R.M. Rodríguez, E. Brillas, N. Oturan, M.A. Oturan, Electro-Fenton degradation of the antibiotic sulfanilamide with Pt/carbon-felt and BDD/carbonfelt cells. Kinetics, reaction intermediates, and toxicity assessment, Environ. Sci. Pollut. Res. 21 (2014) 8368-8378.

[41] M.S. Yahya, N. Oturan, K. El Kacemi, M. El Karbane, C.T. Aravindakumar, M.A. Oturan, Oxidative degradation study on antimicrobial agent ciprofloxacin by electro-Fenton process: kinetics and oxidation products, Chemosphere 117 (2014) 447-454.

[42] I Sirés, F Centellas, J A Garrido, R.M. Rodríguez C. Arias, P. Cabot, E Brillas, Mineralization of clofibric acid by electrochemical advanced oxidation processes using a boron-doped diamond anode and $\mathrm{Fe}^{2+}$ and UVA light as catalysts, Appl. Catal. B Environ. 72 (2007) 373-381.

[43] E.J. Ruiz, A. Hernández-Ramírez, J.M. Peralta-Hernández, C. Arias, E. Brillas, Application of solar photoelectro-Fenton technology to azo dyes mineralization: Effect of current density, $\mathrm{Fe}^{2+}$ and dye concentrations, Chem. Eng. J. 171 (2011) 385-392. 